\title{
How to Close Your Home ${ }^{1}$
}

Virginia Peart ${ }^{2}$

Most people living in Florida have lived in other parts of the country and frequently return to their former communities to visit friends and neighbors. Some people spend part of the year in Florida and part of the year in other areas of the country. Additionally, almost everyone is likely to be away from his home several days or weeks at a time for business or pleasure.

It's always good to return home, yet occasionally we hear of people who return to their Florida homes to find they have a mildew or moisture problem, or the exterior of their house seems to look more rundown when they return. Worse yet, reports of burglary or vandalism appear in the news daily.

What can you do to minimize the possibility that you may return to your home and find a serious problem? Closing Your Home has been developed to help Florida residents make plans for protecting their homes when they are to be absent. There are things you can do to protect your home from moisture problems, deterioration of the exterior, or the intrusion of burglars and vandals.
Air conditioning can be used to reduce potential moisture problems, yet use a minimum amount of energy. As you read or study each section consider the steps you should take in preparing for an extended absence. Many of the suggestions would be wise to follow even when you will be at home.

\section{Interior Procedures}

You have heard the stories of people returning to their Florida homes in the fall and winter greeted by mildew on walls, clothing and furnishings; musty smells and other unpleasant odors; and rusty spots on appliances among other losses. Why do such conditions seem to abound when no one is there?

Remember why you left for the summer? Florida is warm and humid. Pests and organisms such as mildew and bacteria attack organic materials. Wood, cotton, wool, leather and the tiniest traces of dirt or even starch in fabrics can decay, deteriorate and develop odors. Metals are attacked. The slightest scratch through the enamel on a washer or refrigerator exposes the

1. This document is FCS3154, one of a series of the Department of Family, Youth and Community Sciences, Florida Cooperative Extension Service, Institute of Food and Agricultural Sciences, University of Florida. Publication date: January 2003. First published: January 1990. Reviewed: January 2003. Please visit the EDIS Web site at http://edis.ifas.ufl.edu

2. Written by Virginia Peart, former Associate Professor, Housing, Department of Family, Youth and Community Sciences, Cooperative Extension Service, Institute of Food and Agricultural Sciences, University of Florida, Gainesville, 32611 and reviewed by Nayda I. Torres, Professor, Family and Consumer Economics, Department of Family, Youth and Community Sciences, Cooperative Extension Service, Institute of Food and Agricultural Sciences, University of Florida and Dale Dorman, Extension Housing and Environment Specialist - Emeritus, Cooperative Extension Service, University of Georgia.

The Institute of Food and Agricultural Sciences is an equal opportunity/affirmative action employer authorized to provide research, educational information and other services only to individuals and institutions that function without regard to race, color, sex, age, handicap, or national origin. For information on obtaining other extension publications, contact your county Cooperative Extension Service office. Florida Cooperative Extension Service / Institute of Food and Agricultural Sciences / University of Florida / Christine Taylor Waddill, Dean 
base metal to moisture and oxygen in the air. Rust and corrosion follow.

Knowing the rules to Mother Nature's game plan will help you plan a counter-attack before you leave for the summer. There are two important watch words: clean and dry.

\section{Clean}

Food soils and body oils left on towels, articles of clothing, or furnishings absorb water out of humid air and attract mildew fungi and pests such as roaches and ants. It's important to clean thoroughly before you leave.

\section{Kitchen and Laundry}

- Clean each appliance thoroughly. Clean enamel exteriors with sudsy water, rinse and dry. Apply a coating of appliance wax to enamel exteriors to protect scratches from rust. Leave appliances unplugged while you are gone to protect from electrical current surges during summer storms.

- Unopened cans and jars of food can be left on shelves. Flour, sugars and salt should be stored in tightly sealed containers. Dispose of cereals, crackers and pastas to avoid household pests.

- Clean cabinet interiors and exteriors.

- Clean oven, broiler and drip trays under surface units of the range.

- Fresh and perishable foods should be eaten or discarded. Give away or toss opened bottles and jars of salad dressings, condiments, etc., in the refrigerator. It will cost less to replace them if you are gone 2 or 3 months than to run your refrigerator. Clean the refrigerator interior with a solution of 1 tablespoon of baking soda in 1 quart of water to neutralize food soils and prevent odors. Dry thoroughly. Remove and clean the defrost pan behind the grill at the bottom of your refrigerator. The refrigerator and freezer doors should be left ajar.

- Remove any food particles from the filter if one is present in the bottom of the dishwasher. Run the dishwasher through a short cycle. After a few minutes into the cycle, turn off the dishwasher, open the door and clean out around the door gasket and under the bottom of the door to remove any residual soil that might mold in these areas. Complete the cycle. Unlatch the door, but leave it closed to release the pressure on the door seal.

- Clean the disposer by running a batch of ice cubes from the freezer. Run a solution of baking soda and water through the disposer and leave the stopper in place to prevent water from the trap beneath the disposer from evaporating during the summer.

- To remove spatters in a microwave, heat a cup of water in a cool microwave for two minutes on high. Condensation on the walls will loosen spatters. Wash with sudsy water, rinse and dry. If portable model, leave it unplugged.

- Clean portable appliances thoroughly. Be sure to open the trap door under the toaster to remove crumbs and clean.

- Turn off the water supply to the washer to eliminate pressure damage to the hoses. Clean the lint filter, if any.

- Clean the lint filter in the dryer.

- Turn the water heater off if gone for a month or more. For shorter absences, turn the thermostat to its lowest setting. 


\section{Bath}

- Clean all surfaces and fixtures.

- Cover toilet and tank top with a plastic wrap.

- Put stoppers in drains.

\section{Other Rooms}

- Clean and leave a light coating of wax on surfaces of wood furniture.

- Vacuum upholstered furniture (even crevice areas) well. If there are spots and stains, remove or clean before closing the home. Use a commercial upholstery cleaner. Follow directions carefully.

- Leave bedding and bath linens clean and dry. Vacuum mattress thoroughly and cover lightly with a sheet.

- Leave only clean clothes in closets. Allow space between garments to permit circulation of air. Do not leave items on the floor.

Leather shoes, belts, handbags should be cleaned with a leather cleaner. Spray with a disinfectant spray. Do not wrap garments or other items tightly in plastic. This may increase mildew and other problems. Metal hangers, even when covered with paper can rust and stain clothing. Plastic hangers are a must. Leave closet doors open to permit air circulation.

\section{Dry}

\section{Outdoor Moisture}

Since the air in Florida has lots of moisture, it is important that windows and doors be weathersealed to keep moisture out. Bath and kitchen vents can be covered with plastic wrap to seal out moisture. If you have a fireplace, be sure the damper is closed.

\section{Indoor Moisture}

Water from drains and toilets will evaporate and add to the moisture in the house. If all moisture from drain evaporates, sewer gas can come into the home. Drain stoppers should be closed and toilets and tank tops sealed with plastic wrap. Leave house plants outside or with a neighbor. Having someone come in to water plants adds moisture. Turn off water at the meter if it is not used for lawn irrigation. This will prevent flooding if a pipe should break.

\section{Humidity Management}

\section{If You Don't Have Air Conditioning}

The temperature in your home will rise during the heat of the day when you are away in the summer. This temperature rise will actually result in a lower relative humidity. This may inhibit moisture related problems if enough moisture is kept out of your house by the methods prescribed earlier. Desiccants that do not liquify may help keep moisture down in enclosed spaces that are tightly sealed such as in an air-tight trunk.

A dehumidifier operated by a drain to carry moisture away can be a help though it will not be as useful as air conditioning.

If you plan to use a chemical mildew inhibitor, see IFAS publication, FCS 3243, Chemical Mildew Inhibitors -- Should I Use Them? How?

For additional information about mildew control, see IFAS publication, FCS 3042, How To Prevent and Remove Mildew.

\section{Air Conditioning Considerations}

There is no reason to maintain comfortable living temperatures when you are away in the summer; however, periodic air conditioner 
operation will remove moisture from your home. To assure the continued effective operation of your air conditioner and to prevent excessive energy use, follow these suggestions.

\section{Leave Your Air Conditioner in Good Condition}

Just before you leave is a good time for an air conditioner check-up by a professional, but there is some checking you can do:

- Air conditioning filter. Change it or if washable, wash it. An accumulation of dirt plus the summer heat and humidity can cause mildew and mold growth which can spread through the house.

- Leakage. Check around the edges of window air conditioners for leakage. Tape any leaks with approved duct tape.

\section{A Professional Check-up Will Additionally:}

- Clean the blower wheel and coil.

- Check the temperature drop across the cooling coil and add refrigerant if needed.

- Adjust tension on belts.

- Check the thermostat.

- Inspect wiring and connections.

- Clean the condensate pan and pipe.

- Check the operation of motors.

\section{Operate Your Air Conditioning to Save Energy}

Running your air conditioner for two hours a day when your house is closed and sealed will reduce potential development of mildew. The air conditioner should be equipped with a timer set to operate in the cool morning hours, beginning at 3 or 4 a.m. Set the thermostat low enough to operate continually during the 2-hour period.
CAUTION: The use of a humidistat to control the operation of an air conditioner may cause problems since it can be difficult to operate properly. If set too low or not properly calibrated, it will cause the air conditioner to run too long, waste energy and result in high electric bills.

\section{Calculating the Cost of Air Conditioning}

First estimate kilowatt hours (KWH) using the BTU rating of the air conditioner, the Energy Efficiency Ratio (EER) from the yellow label on a new air conditioner and the hours the air conditioner will be used. See Table 1.

Table 1.

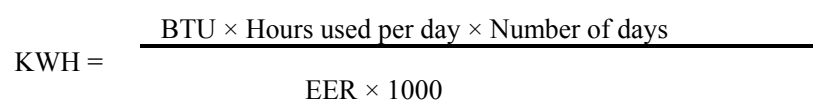

Example: A 3-ton air conditioner, which uses 12,000 BTU per ton, or $36,000 \mathrm{BTU}$, with an EER of 6, operating for 2 hours per day for a month (30 days) would use:

$$
\begin{aligned}
& \mathrm{KWH}= \frac{36,000 \mathrm{BTU} \times 2 \text { hours. } \times 30 \text { days }}{6 \times 1000} \\
&= 360 \mathrm{KWH} \text { per month } \\
& \text { Cost to operate for a month if the electricity rate is } \$ 0.09: \\
& \text { Cost }(\$)=\mathrm{KWH} \times \text { Electricity Rate } \\
& \text { Cost }=360 \mathrm{KWH} \times \$ 0.09 \text { per KWH } \\
& \text { Cost }=\$ 32.40
\end{aligned}
$$

\begin{tabular}{lcc}
\cline { 2 - 3 } 3-ton $\mathrm{A} / \mathrm{C}(\mathrm{EER})=6)$ & $\$ 32.40$ & $\$ 36.00$ \\
3 -ton $\mathrm{A} / \mathrm{C}(\mathrm{EER})=8)$ & 24.30 & 27.00 \\
2 21/2-ton $\mathrm{A} / \mathrm{C}(\mathrm{EER}=6)$ & 27.00 & 30.00 \\
2 21/2-ton $\mathrm{A} / \mathrm{C}(\mathrm{EER}=8)$ & 20.25 & 22.50 \\
$*$ Cost per month & &
\end{tabular}

These amounts are considerably less than operating your air conditioning continuously, but in a tightly constructed house they may be sufficient to reduce the probability of mildew problems.

\section{Exterior Planning}

Warm weather in Florida is hard on housing that is not in good repair. Heavy seasonal rains 
will drive water inside the structure where defects exist. Algae and mildew will thrive if conditions are right. Before you leave for an extended period it is wise to check the exterior of your house to make sure it is in tip-top shape.

Many condominium or manufactured home parks take care of some or part of the exterior maintenance. People who live there must check with the management to see what their responsibilities for care and maintenance are during a period of absence.

\section{Foundation of the House}

- Whether a house is on a slab or over a crawl space or a basement (basements are rarely used in central or southern Florida), the grading of the ground should direct rain water away from the house.

- Exterior wood on a house should be high enough from the ground that it won't get wet during a downpour. With a wide over-hang, lower exterior walls are less likely to get wet.

- Landscaping around the foundation of a house should be placed far enough away from the house (two feet or more) to permit air to flow freely and prevent high humidity areas that allow algae and mildew to grow.

- The crawl space, if there is one, should not have standing water after heavy rains and should be well ventilated.

\section{Roof and Gutters}

- Neglect and damage to roof and gutters can result in leaks, seepage and decay problems.

- Check for damaged, curled, loose or missing shingles.

- Check flashing around chimneys and vents for damage.
- Remove leaves and debris from gutters and downspouts. Check gutters and downspouts for damage. Observe after heavy rain to see if water is flowing freely in them.

- Remove accumulations of debris from roof.

\section{Exterior Walls}

- Exterior walls should be free of leaks that would let water from rains or moisture in the air enter a house in warm, humid climates.

- Check masonry walls for cracks or loose mortar.

- Painted walls should not have mildew, cracks or blisters.

\section{Windows and Doors}

- Look for gaps between windows or doors and walls. Use caulking to fill in.

- Replace broken or cracked putty as well as weatherstripping that is loose or damaged.

\section{Swimming Pool}

Your pool should be thoroughly cleaned before you leave. It is important to maintain the pool regularly. A reliable pool maintenance service should check every 7 to 10 days to make sure the pool $\mathrm{pH}$ and chemical balance are correct. Untreated or under-treated will result in algae growth. Do not drain pool as the sun can dry it out and cause it to crack. If there is considerable rain, pressure can build up outside the empty pool causing it to crack.

\section{Shrubbery and Lawn}

Regular trimming and mowing must be arranged to keep plants from taking over. 


\section{Security Considerations}

When you will be away from your home for either a short or long period, it pays to plan for protection of your home and possessions from burglars or intruders. Five important considerations are:

1. discouraging the interest of burglars,

2. inhibiting entry into your home by an intruder,

3. disrupting a break-in when it is happening,

4. protecting valuables left in your home,

5. covering potential burglary losses.

It is wise to become friends of neighbors who may be at home during your absence. You can trade-off helping to protect each other's homes and make your neighborhood more secure.

If you live in a condominium or planned community, some security may be provided. Know what is provided and make arrangements to cover your responsibilities.

\section{Discourage Interest of Burglars}

The best defense is prevention. Both amateur and professional burglars are likely to bypass houses that appear to have active residents at home. Your house should have a lived-in look.

- Mail, newspapers and other deliveries should be stopped or promptly picked up by a friend or neighbor.

- A car parked in the drive or carport discourages burglars. A friend or neighbor may agree to leave his or her car in your drive.
- Don't disconnect your phone. Some answering/message machines can be accessed by long distance to pick up messages. You can even change your message to the caller from long distance.

- Several lights within a home should be placed on timers to simulate movement within the house suggesting normal activities.

- Outside lighting and trimmed shrubbery should provide nighttime visibility of windows and doors from the street and other houses in the neighborhood.

- Outside lights left on during the day may signal that you are gone for an extended period.

- Don't leave clues that you are to be away. Don't announce your plans in the newspaper or talk about it casually in public places.

- Window treatments should not make the house look closed-up, but should not permit easy viewing of valuables within the home such as electronic equipment and cameras.

\section{Inhibiting Entry by an Intruder}

If, in spite of your efforts to make your house look lived-in, a burglar decides to try to break in, don't make it easy.

- All doors should have secure locks; a dead bolt or jimmy-proof lock on each door.

- Glass panels in doors or next to doors should be shatter proof or double glazed.

- Locks in doors with glazed windows or side panels should include one that can be opened from the interior only by a key. The key should not be left in the lock. 
- Sliding glass doors should have a bolt-type lock to prevent its being lifted out of its track plus a jamming bar in the inside track. Glass in sliding glass doors should be shatter proof, double glazed or have a break-resistant plastic sheeting.

- Clear plastic film on windows can make them more difficult to break and slow the progress of a burglar.

\section{Disrupting a Break-In}

Electronic or mechanical door and window alarms can frighten a burglar away if your house is close enough to neighbors for the alarms to be heard. Perimeter sensor systems, window-foil or glass breakage sensors will help in the same way.

House alarm systems to inhibit the progress of burglars include undercarpet sensing devices, passive infrared, ultrasonic, microwave and photo electric beam alarm systems. The more sensitive and reliable alarm systems are likely to cost more. Look for the Underwriters Laboratories seal of approval for a system that has been tested for performance and safety.

\section{Protecting Valuables}

Burglars are eager to take items that have a ready market value. The value of items drops when these items have identification and can be traced to the original owner.
Valuables such as jewelry, watches and other items should not be left behind when you leave. Place them in a safety deposit box.

Cameras, electronics, silver and appliances should have your social security number, car license number or name engraved on the bottom. Engraving equipment can frequently be borrowed from your police department. Participants in the Operation Identification Engraving program receive window stickers announcing that possessions are marked. This will inhibit most burglars.

\section{Covering Potential Burglary Losses}

Most homeowners' policies provide some protection against burglary. Don't take your insurance for granted. Check to see if theft protection is provided and if your valuables will be adequately covered.

If a list of items is required, provide that list. Make sure you meet all requirements. Check the fine print to be sure of your protection.

Whether or not it is required, it may be wise to have well-lighted, clear photographs or pictures of items that would be costly or difficult to replace. 